\title{
Three-Dimensional Morphodynamic Modelling of Tigris River in Baghdad
}

\author{
Ammar A. Ali ${ }^{1,2}$, Nadhir A. Al-Ansari ${ }^{1}$, Qusay Al-Suhail ${ }^{3}$, Sven Knutsson ${ }^{1}$ \\ 1. Department of Civil, Environmental and Natural Resources Engineering, Lulea University of Technology, 97187, Lulea, Sweden; \\ 2. College of Engineering, University of Baghdad, Baghdad 10001, Iraq; \\ 3. College of Science, University of Baghdad, Baghdad 10001, Iraq
}

\begin{abstract}
Bathymetric and land surveys were conducted for the northern Tigris River reach (18 km length) in Baghdad, producing 180 cross sections. A river bed topography map was constructed from these cross sections. The velocity profiles and the water discharges were measured using ADCP (Acoustic Doppler Current Profiler) at 16 cross sections, where intensive number of sediment samples was collected to determine riverbed characteristics and sediment transport rate. The three-dimensional morphodynamic model (SSIIM (simulation of sediment movements in water intakes with multiblock option)) was used to simulate the velocity field and the water surface profile along the river reach. The model was calibrated for the water levels, the velocity profiles and the sediment concentration profiles using different combinations of parameters and algorithms. The calibration and the validation results showed good agreement with field measurements, and the model was used to predict the future changes in river hydro-morphology for a period of 14 months. The results of the future predictions showed the Tigris River which behaved like an under-fit river, increases in depositions on the shallow part of the cross section having lower velocity, and the river deepens the incised route to fit its current hydrologic condition leaving the former wide section as a floodplain for the newer river. The net deposition/erosion rate was $67.44 \mathrm{~kg} / \mathrm{s}$ in average and the total deposition quantity was 2.12 million ton annually. An expansion in the size of current islands was predicted. An indication of the potential threats of the river banks' collapse and the bridge piers' instability was given by high erosion along the thalweg line.
\end{abstract}

Key words: 3D modeling, SSIIM, bed changes, sediment transport, ADCP velocity measurements, sand bed, under-fit river, Tigris River.

\section{Introduction}

Estimating erosion and sedimentation rates and their locations along river's reach can be as important as estimating flow and velocity for preparing future plans. These estimations require a good knowledge of the effective variables that control the processes, as well as understanding the relationships which control these variables. Discharge, flow velocity, bed material, sediment supply and channel slope are the major effective variables that control the erosion and sedimentation processes.

In the past, estimation of velocity was achieved by using physical models jointly with field measurements. However, after the great development in computational

Corresponding author: Nadhir Al-Ansari, professor; research fields: water resources and environment. E-mail: nadhir.alansari@ltu.se. methods and computer capabilities, simulation models became popularly used for this purpose. Usually simulation models use some of the well-known equations such as Navier-Stokes equations established based on conservation concepts such as conservation of mass and momentum to govern the relationships between the control variables in the treated phenomena. Moreover, simulation models started coupling many models together (such as hydrodynamic, sediment transport and morphology models) to reach for the integrity in the subject of erosion and sedimentation.

Simulation models are powerful and relatively inexpensive tools for predicting future morphological changes, evaluating alternatives of river control works, and environmental management of the river. The reliability and the accuracy of a simulation model's 
performance in reproducing field conditions of real-life problems in the model are questionable unless they are subjected to calibration and validation processes to adjust to the parameters and the algorithms of the model and re-examining the results for different site conditions.

Field investigations and measurements are necessary to provide simulation models with different sets of values for the important variables in the model, such as flow velocity, water level and sediment concentrations. These variables are to be used for comparisons with model results during calibration and validation steps.

The SSIIM (simulation of sediment movements in water intakes with multiblock option) model is a three dimensional morphodynamic model that is used to simulate velocity field, water surface profile, sediment transport, morphological changes as well as pollution dispersion in rivers and reservoirs with high flexibility for dealing with complex geometries. It couples several models (convection-diffusion, transport-dispersion and sediment continuity models) with geometry editor and input file for pre-processing step and graphical display package for post-processing step [1].

In this research, $18 \mathrm{~km}$ reach of the River Tigris was studied and the data were used in SSIIM 3-D model to predict future changes expected in the reach.

\subsection{Tigris River}

Tigris River bisects Baghdad, the capital of Iraq, into two parts for a distance of about $50 \mathrm{~km}$ within the urban zone starting from Al-Muthana Bridge to the north and ending at the confluence with the River Diyala to the south. This river reach has single thread, compound meanders, and alluvial plain characteristics. The river banks are protected against erosion for $66 \%$ of the length in the urban zone by aligned stones and cement mortar between levels 29 and 37 m.a.s.l. at the start of the reach and drop gradually to the south. Recently, the dominant water levels in the reach are below the protection level.
The flow of the river is fully controlled in Baghdad by a system of dams and regulators constructed on the main river and the tributaries upstream of Baghdad. The river discharge was reduced $44 \%$ of previous period. The discharge dropped to $522 \mathrm{~m}^{3} / \mathrm{s}$ as a monthly average flow of the period (2000-2013). The flow peaks, when most of the sediment was transported during them [2], had been vanished due to the effect of the regulating schemes in Iraq and Turkey as well as climate change where a drought period is affecting the region [3-6].

During the last two decades, many new islands, side depositions and point bars appeared in the Tigris River's reach in Baghdad (Fig. 1). Eighteen obstacles between islands and sandbars were recognized inside Baghdad in 2008 [7-9]. Dredging operations have been started at specified sites along the river inside Baghdad to overcome the sedimentation problems. However, deposition processes are still active along the river and some of the completed dredging sites need to dredge again. Accordingly, the estimation for sedimentation rate and predicting the future changes in the riverbed topography of Tigris River are required.

The northern reach of Tigris River in Baghdad of length $18 \mathrm{~km}$ was considered as a study reach in this work. It extends from Al-Muthana Bridge at the north of the city until Sarai Baghdad gauging station at the center of the city (see Fig. 1). The aims from this work are:

(1) investigating the zones of erosion and sedimentation along the study reach;

(2) determining the rate of sedimentation in the study reach;

(3) predicting the future changes in the riverbed topography along the study reach.

To achieve these aims, the SSIIM was used for simulating the flow field and sediment transport during calibration and validation steps by the assistant of field measurements of water levels, velocity distribution and sediment load, which are preparing the model for predicting the future changes of bed topography. 


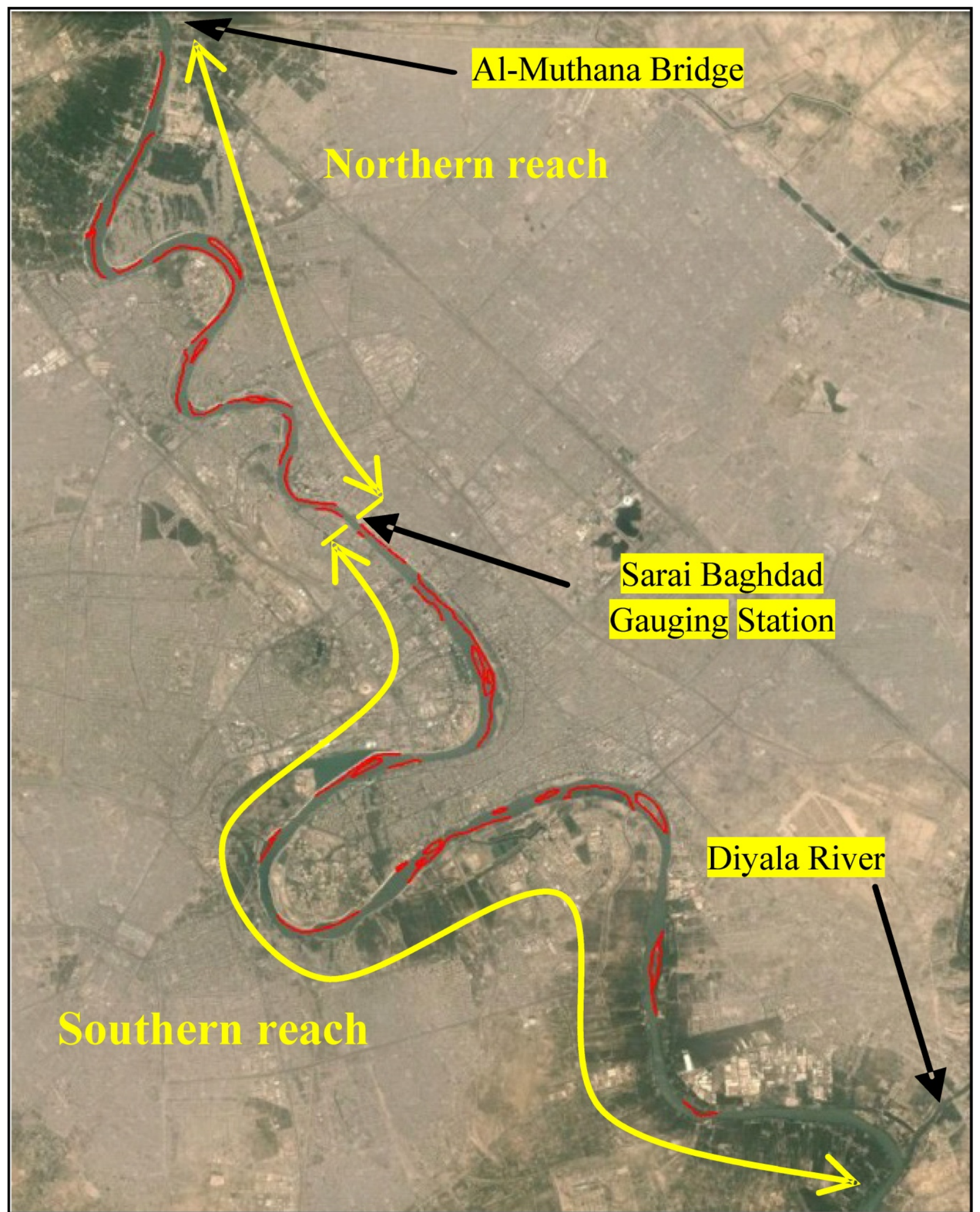

Fig. 1 The Tigris River inside Baghdad (the islands and sandbars were bordered by red). 


\section{River Bathymetry and Field $G_{t}$ : total sediment discharge $(\mathrm{kg} / \mathrm{s})$; Measurements \\ $Q_{w}$ : water discharge $\left(\mathrm{m}^{3} / \mathrm{s}\right)$.}

The study reach consists of a series of 7 meanders (Fig. 2) of radii of curvature that are ranging from $475 \mathrm{~m}$ to $1,245 \mathrm{~m}$ [10]. Two islands existed in the river reach. The smaller one is located in the upstream of CS4 directly and the second (which is larger) is within CS6-1 and CS6-4.

Bathymetric survey was conducted to the riverbed and land survey to the river banks at 180 cross sections along the reach to produce high quality topographical map for the river course as shown in Fig. 3. The riverbed elevations ranged between 13.5 and 28.76 m.a.s.l. The deepest locations are on the outer banks of the meanders in the part directly downstream from the peaks. The map showed depositions near water surface at level between 27 and 28.76 m.a.s.l.

Using the van Veen grab, 46 bed sediment samples were extracted along the reach to determine the characteristics of the material on the bed. Fine sand is the dominant on the riverbed and 9 particle sizes were recognized in the whole reach ranging from clay to medium sand. The results of the analysis of the bed sediment samples were presented in Ref. [11].

Water discharge and velocity distribution were measured in 16 cross sections (see Fig. 2) using Son Tek River Surveyor M9 ADCP with repetitions for more accuracy. Additional measurements for flow velocities were measured at certain depths of shallow water using FP111 global water flow probe.

Total load transport rates were determined in 16 cross sections by collecting 288 bedload samples using the Helley-Smith sampler and 212 suspended load samples suction pump, and then combining the analysis results to get the total load. A total load rating curve (Eq. (1)) was established using the total load transport rates. The details of the analysis of the sediment samples were published in Refs. [12, 13]:

$$
G_{t}=0.0002 Q_{w}^{2.1312}
$$

where:

\section{The SSIIM Model}

The using of the SSIIM model required preparing several issues before starting to run the model. These issues can be categorized as follows:

(1) Geometry

a. geometry grid;

b. bathymetry of the river;

(2) Hydrodynamic

a. initial water surface profile;

b. boundary conditions;

c. bed composition and roughness;

(3) Morphology

a. sediment fractions;

b. sediment boundary and transport;

(4) Calibration and validation

a. water levels;

b. flow velocities;

c. sediment concentrations.

\subsection{Model Geometry}

A geometry grid was prepared for the river bed and lower banks. The size of the grid was chosen in a way to make a balance between the accuracy of the grid to represent the details of the complicated topography of the river as well as satisfy the stability requirements of the model solution and between computational time's consumption. The horizontal size of the grid was 90,000 cells and the length to width ratio of the grid cells was not larger than 3 . The bathymetric and land surveys' data were converted to geometry points and interpolated over the constructed grid.

\subsection{Hydrodynamic and Morphology}

An initial water surface profile was considered from previous simulation for 1-D flow in the river for a discharge close to the average monthly flow [8], then the model adjusted the water profile for the current hydraulic conditions using free surface algorithms. The 


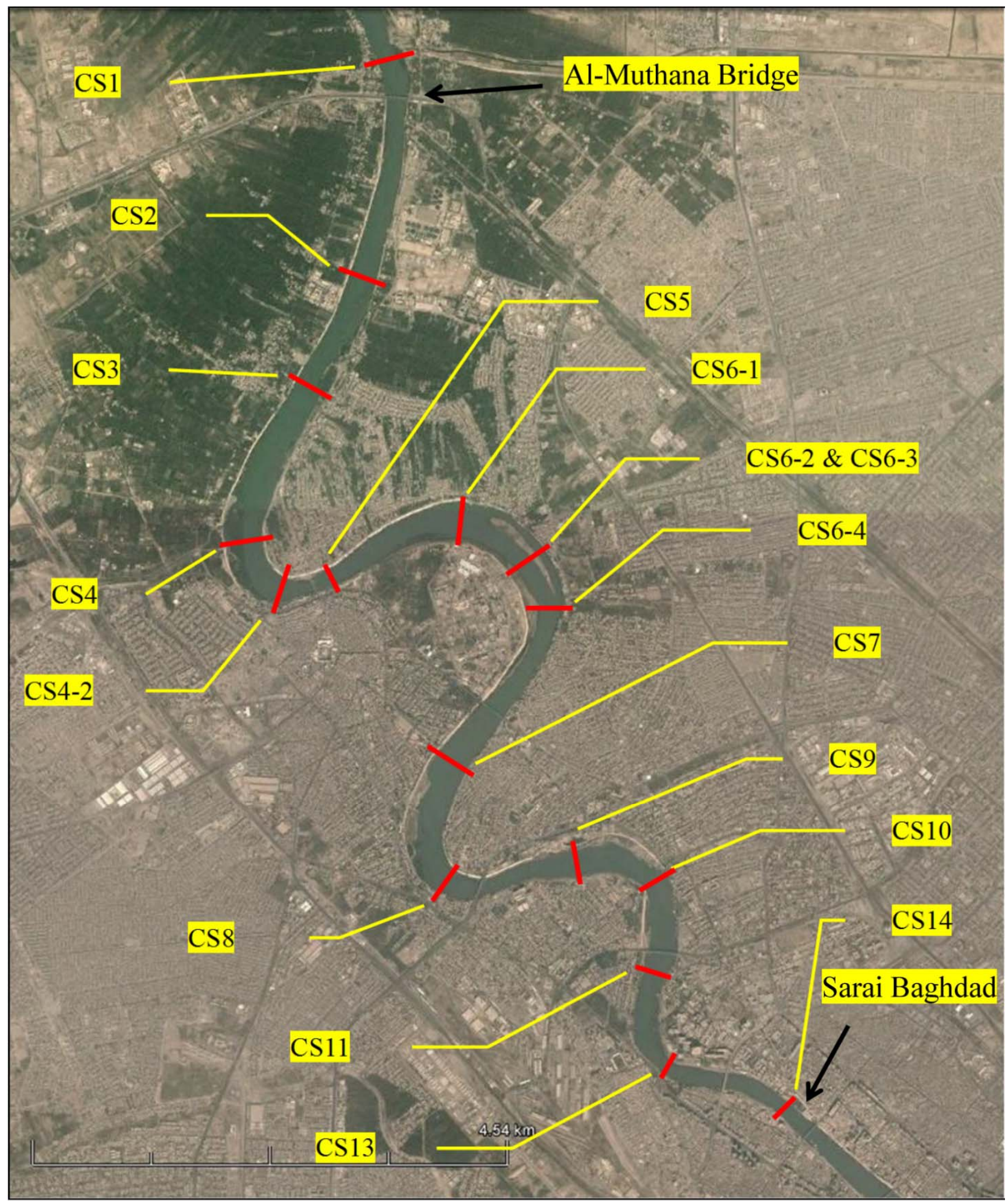

Fig. 2 Cross sections of sediment sampling and ADCP measurements along the northern reach of the Tigris River. 


$$
\xi
$$


upstream boundary condition was dependant on water inflow while the downstream boundary condition was dependant on specifying the water level corresponding to water inflow.

The results of the analysis for the bed material samples were used to prepare a distribution map for bed sediment fractions for all bed grid cells. The bed roughness was either calculated from Manning's roughness coefficient $(n)$ or from $d_{90}$ of particle size distribution and bedform height based on the sediment fractions map for bed grid cells.

Settling velocities for the sediment fractions in the riverbed were determined using Rubey settling velocity for the sizes up to $50 \mu \mathrm{m}$, for smaller sizes, Stokes settling velocity was used as shown in Table 1.

The total load rating curve (Eq. (1)) was used to specify the sediment inflow.

\subsection{Calibration and Validation}

To evaluate the accuracy and the validity of the simulation model, holding a comparison between the results of the model with the field measurements of water level, flow velocity and sediment concentration are essentially and extremely important. By evaluating the size of the differences (errors) between results and measurements, one can accept or refuse the model's results, the minimum differences are indicative of a higher quality of simulation. Another set of measurements need to be used for the validation rather than the used for the calibration.

In morphodynamic models, calibration can be achieved by adjusting several parameters, those assumed initially according to the experiences in the application field. The calibration parameters considered for this work are listed below with their selected values:

(1) bed roughness ( $n=0.02, n=0.025, n=0.0286$, $n=0.04,3 d_{90}$ /bedform);

(2) water surface profile algorithm (back water, pressure field);

(3) turbulence model (standard $k-\varepsilon$, local $k-\varepsilon$ );

(4) simulation time step ( $6 \mathrm{~h}, 1 \mathrm{~h}, 1 / 4 \mathrm{~h})$;

(5) discretization scheme (POW (first order upwind), SOU (second order upwind));

(6) No. of internal iterations (100, 150, 1,000);

(7) sediment formula (suspended load, total load);

(8) active layer thickness ( $0.1 \mathrm{~m}, 0.2 \mathrm{~m})$.

Field measurements were conducted during a range of water flows between 450 and $645 \mathrm{~m}^{3} / \mathrm{s}$. The flow $530 \mathrm{~m}^{3} / \mathrm{s}$ is the closest discharge to the monthly average and was selected to be used for model calibration and a higher discharge $\left(645 \mathrm{~m}^{3} / \mathrm{s}\right)$ was selected for the validation of the model.

Calibration processes were repeated 39 times for different combinations of calibration parameters. Of these, 28 trials were designed for hydrodynamic part or parameters; such as bed roughness, a water surface algorithm, a turbulence model, the computational time step, a discretization scheme and number of internal iterations, while the remaining 11 trials were used for the sediment concentration part; such as the entrainment algorithm, the sediment formula and the active layer thickness.

Table 1 Sediment fractions of bed material with settling velocity.

\begin{tabular}{ll}
\hline Particle size $(\mathrm{mm})$ & Settling velocity $(\mathrm{m} / \mathrm{s})$ \\
\hline 0.3 & 0.041709 \\
0.15 & 0.01748 \\
0.075 & 0.005159 \\
0.05 & 0.002344 \\
0.0135 & 0.000134 \\
0.008 & $4.71 \mathrm{E}-05$ \\
0.006 & $2.65 \mathrm{E}-05$ \\
0.004125 & $1.25 \mathrm{E}-05$ \\
0.0015 & $1.66 \mathrm{E}-06$ \\
\hline
\end{tabular}


RMSE (root mean square error) was used as indication of the differences between the simulation results and measurements. For the first group of parameters, RMSE was calculated for water levels and velocity profiles, while for the second group, RMSE was calculated for sediment concentration profiles. The field measurements for CS9 and CS13 were used in the calibration processes because they were measured at the same flow rate, $530 \mathrm{~m}^{3} / \mathrm{s}$. The RMSE for the whole calibration trials was listed briefly in Tables 2 and 3.

An overview of the calibration results in Table 2 shows that most of the results are approximately identical. However, some of these parameters and algorithms were given smaller RMSE and they have to

Table 2 RMSE values for water level $(\mathrm{m})$ and velocity profile $(\mathrm{m} / \mathrm{s})$ for calibration of hydrodynamic parameters.

\begin{tabular}{lll}
\hline WSP (water surface profile) algorithm & WL & Velocity \\
\hline BW & 0.149 & 0.108 \\
PF (pressure field) & 0.104 & 0.105 \\
\hline Turbulence model & & 0.106 \\
\hline Local $k$ - $\varepsilon$ & 0.102 & 0.105 \\
Standard $k$ - $\varepsilon$ & 0.104 & \\
\hline Discretization scheme & & 0.105 \\
\hline POW & 0.104 & 0.108 \\
SOU & 0.104 & \\
\hline Time step & & 0.105 \\
\hline 6 & 0.104 & 0.105 \\
1 & 0.104 & 0.105 \\
$1 / 4$ & 0.104 & \\
\hline Roughness & & 0.105 \\
$n=0.02$ & 0.104 & 0.116 \\
$n=0.025$ & 0.102 & 0.127 \\
$n=0.0286$ & 0.140 & 0.166 \\
$n=0.04$ & 0.190 & 0.102 \\
$3 d_{90}$ & 0.104 & 0.102 \\
$3 d_{90}+$ bedform & 0.104 & \\
\hline Internal iterations & & 0.105 \\
100 & 0.104 & 0.107 \\
150 & 0.104 & 0.102 \\
\hline
\end{tabular}

Table 3 RMSE values for sediment concentration profile $(\mathrm{mg} / \mathrm{L})$ for calibration of sediment parameters.

\begin{tabular}{ll}
\hline Entrainment & Concentration \\
\hline Yes & 0.094 \\
No & 3.104 \\
\hline Sediment load & \\
\hline Yes & 0.057 \\
No & 0.094 \\
\hline Sediment formula & \\
\hline Suspended load & 0.084 \\
Total load & 0.057 \\
\hline Active layer thickness & \\
\hline 0.1 & 0.037 \\
0.2 & 0.052 \\
1.0 & 0.057 \\
\hline
\end{tabular}


be considered for the validation process. Explanation for the importance of these parameters and their effects can be discussed in following points:

(1) Water surface profile algorithm, pressure field, gave better results than the backwater algorithm for both water levels and velocity profiles;

(2) Both turbulence models, local $k-\varepsilon$ and standard $k-\varepsilon$, gave approximately similar results. The local $k-\varepsilon$ model is based on the water velocity and its algorithm was not explained clearly in the documents of the SSIIM model, so the standard $k-\varepsilon$ is preferred;

(3) Although the SOU (second order upwind) scheme has an advantage over the POW (first order power) law scheme because it takes into consideration the first order derivative of the partial differential equation, while the POW scheme ignores it, the POW scheme gives less RMSE for the velocity than the SOU scheme. However, the SOU will be considered in the following steps because of its order of accuracy and to reduce the possible false diffusion in the convection term, as well as the difference between RMSE for both of them is negligible;

(4) There is no apparent effect of the time step size on the calibration results, which may return to the steady state flow that was considered in the calibration. However, as soon as the sediment transport process starts and erosion and sedimentation processes develop, the importance of the time step size will arise due to developing the changes in bed and the associated changes in water depth and velocity vector. The smaller the time step is, the more stable the solution and the longer the time of computations are. A one-hour time step will be considered in the next steps unless stability requirements impose smaller one;

(5) Roughness is one of the most important parameters in the set. Many of results' magnitudes and accuracies depend on the bed roughness value; such as the water surface profile and velocity profile. Bed roughness is either computed from Manning's roughness coefficient or from bed sediment grain size and bed form height. The later one gives a smaller
RMSE, so it will be used in the next steps;

(6) At each time step, there are number of internal iterations for resolving the system of equations to reduce the residuals of the variables. Increasing number of internal iterations is required the convergence in the solution; on the other hand, it will increase the computational time effectively if the grid has huge number of cells. Internal iterations between 200 and 500 were considered.

The other set of parameters are those that affect the sediment concentration profile (Table 3) which were given a wider variance of RMSE values. Discussion of their values and the corresponding RMSE are outlined in the following points:

(1) An algorithm that can invoke the SSIIM model to convert the computed sediment concentrations to sediment entrainment rates for the bed cells is by using the sediment formula [1]. Using this algorithm gives RMSE significantly lower values than those computed without the entrainment algorithm;

(2) Applying sediment load according to the sediment rating curve improved the concentration profile and reduced the RMSE. Otherwise, the computation of the concentration profile will be based only on the erosion rate from the bed;

(3) The Van Rijn bedload formula [14] and suspended load formula [15] can be used separately or combined in the SSIIM model. Combining them together will compute the total sediment load. The RMSE relating to total load computation was less than the one for suspended load alone;

(4) The river bed can be simulated by two layers, active and inactive. The active layer is the top one and it has a constant thickness during simulation time. The active layer interacts with the flow and any erosion or sedimentation will compensate to/from the inactive layer. Zhang et al. [16] found that the thickness of the active layer has to be considered as a calibration parameter. It often equated to half of the average bedform height [17] or even more up to 1.5 times the sand dune height $[18,19]$. The calibration processes 
showed that it was the active layer thickness $0.1 \mathrm{~m}$ that gives smaller RMSE.

As a result of the calibration processes, the easting and northing components of the calibrated velocity profiles at CS9 and CS13 are shown together with the measured profiles in Figs. 4 and 5, respectively. The calibrated sediment concentration profiles are shown in Fig. 6 together with the measured concentration profiles.
The simulated depth-averaged velocity distribution of the Tigris River is shown in Fig. 7, where the velocity ranged between $0.07 \mathrm{~m} / \mathrm{s}$ at stagnant locations close to the banks and $1.35 \mathrm{~m} / \mathrm{s}$ at some locations along the deep route. The velocity field is affected by the precision of the geometry shape, where dispersion can be noted at certain locations which can be attributed to the discretization in the bathymetric survey and to the flow disturbance due to dredging operations.

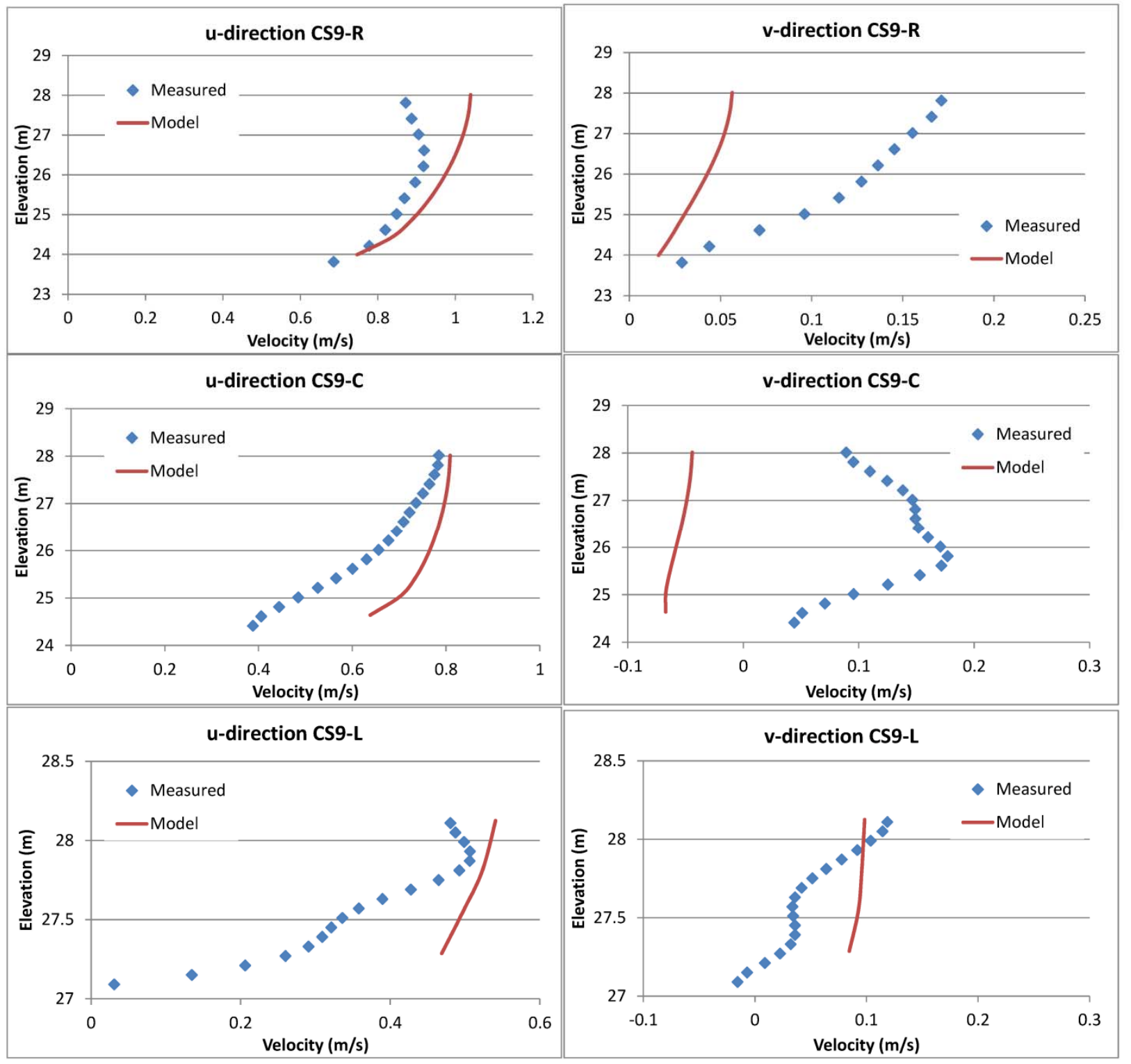

Fig. 4 The calibrated and the measured velocity profiles of CS9. 


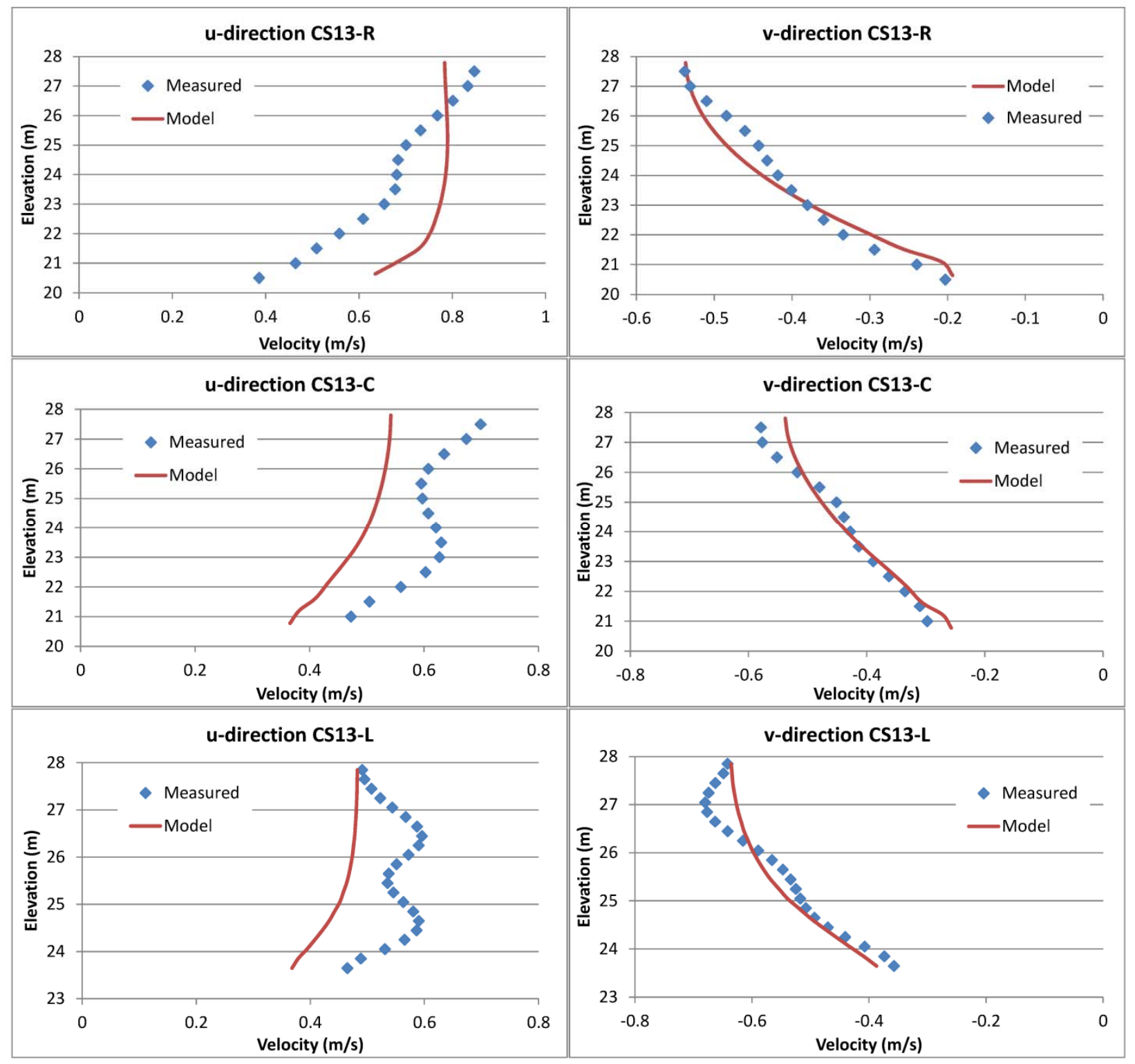

Fig. 5 The calibrated and the measured velocity profiles of CS13.

The measurements of ADCP for the depth-averaged velocity profiles were compared with the simulated velocity field and it was found that the flow directions were compatible in the most of the measurements as shown in Fig. 8. However, a few incompatibilities were found at some locations of circulation and they might be attributed to the false diffusion related to the discretization scheme [19, 20].

The validation process was applied to a water flow of $645 \mathrm{~m}^{3} / \mathrm{s}$ using the chosen set of parameters and algorithms from the calibration step. A new water surface profile was computed for the new water flow. The inflow of sediment discharge was set according to the water flow. To examine the model validation, the new simulation results were compared with another set of measurements which included water levels, velocity profiles and sediment concentration profiles. The RMSEs were determined for the validation step as shown in Table 4.

The results in Table 4 show that the values of RMSE for the validation process were of the same magnitudes for calibration processes. Accordingly, the model can 


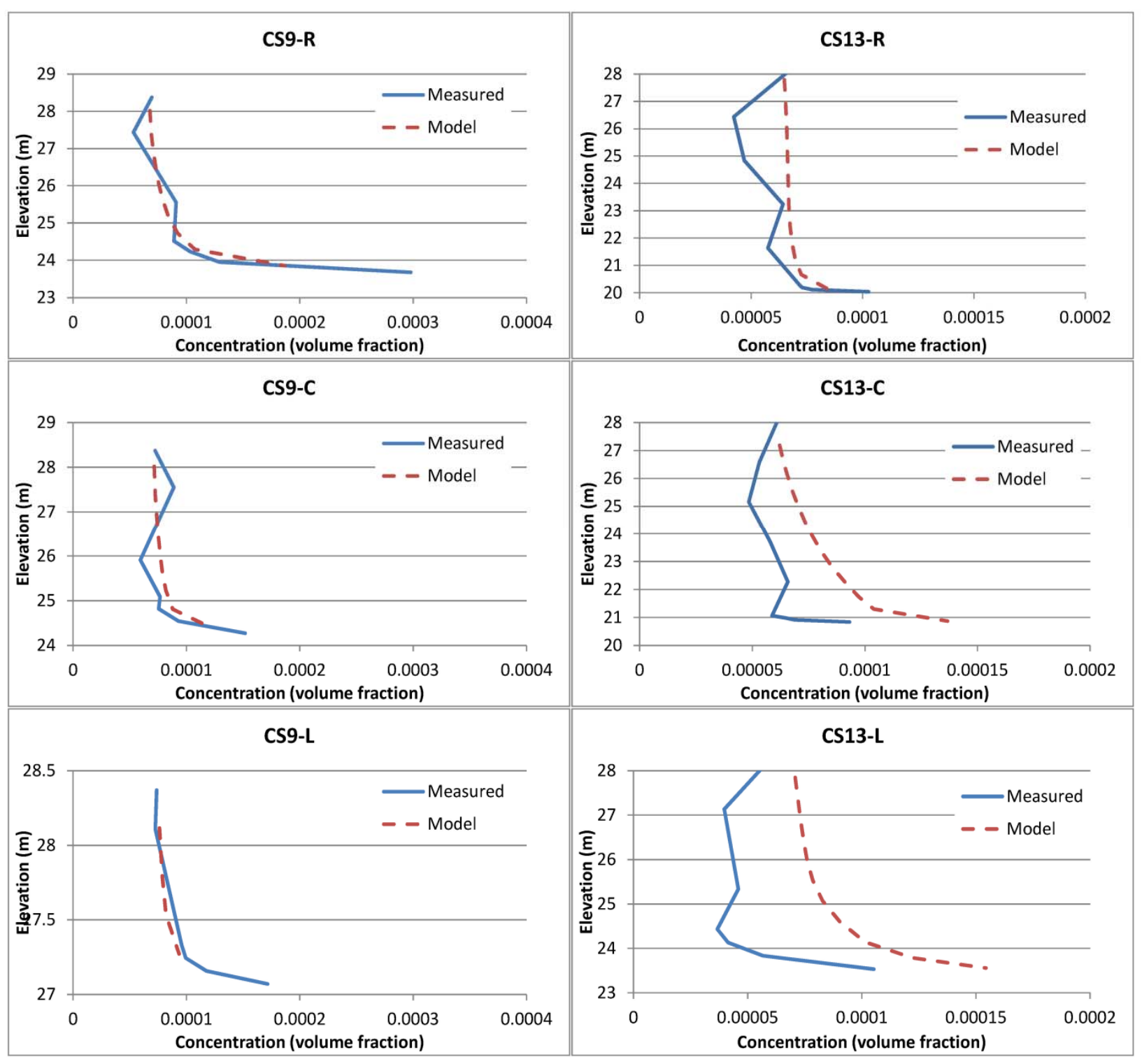

Fig. 6 The calibrated and the measured sediment concentration profiles of CS9 and CS13.

be considered valid for simulating water surface, velocity field and sediment concentrations for Tigris River reach.

\subsection{Future Prediction}

To predict the future changes in any river system accurately, knowledge about the future changes in the controlling variables (such as water flow, extra sources of sediment supply, human activities, and so on) must be satisfied. This will guide the model user to adjust the parameters at the appropriate simulation time to keep the model results on track. Otherwise, the future prediction will be limited to the present knowledge of the river conditions. Significant changes can occur to the controlling variables which should be taken into consideration; otherwise unrealistic results might be produced by the model.

After satisfying calibration and validation processes, the SSIIM model can be used for predicting the future changes of river bed topography and the velocity field 
Three-Dimensional Morphodynamic Modelling of Tigris River in Baghdad

583

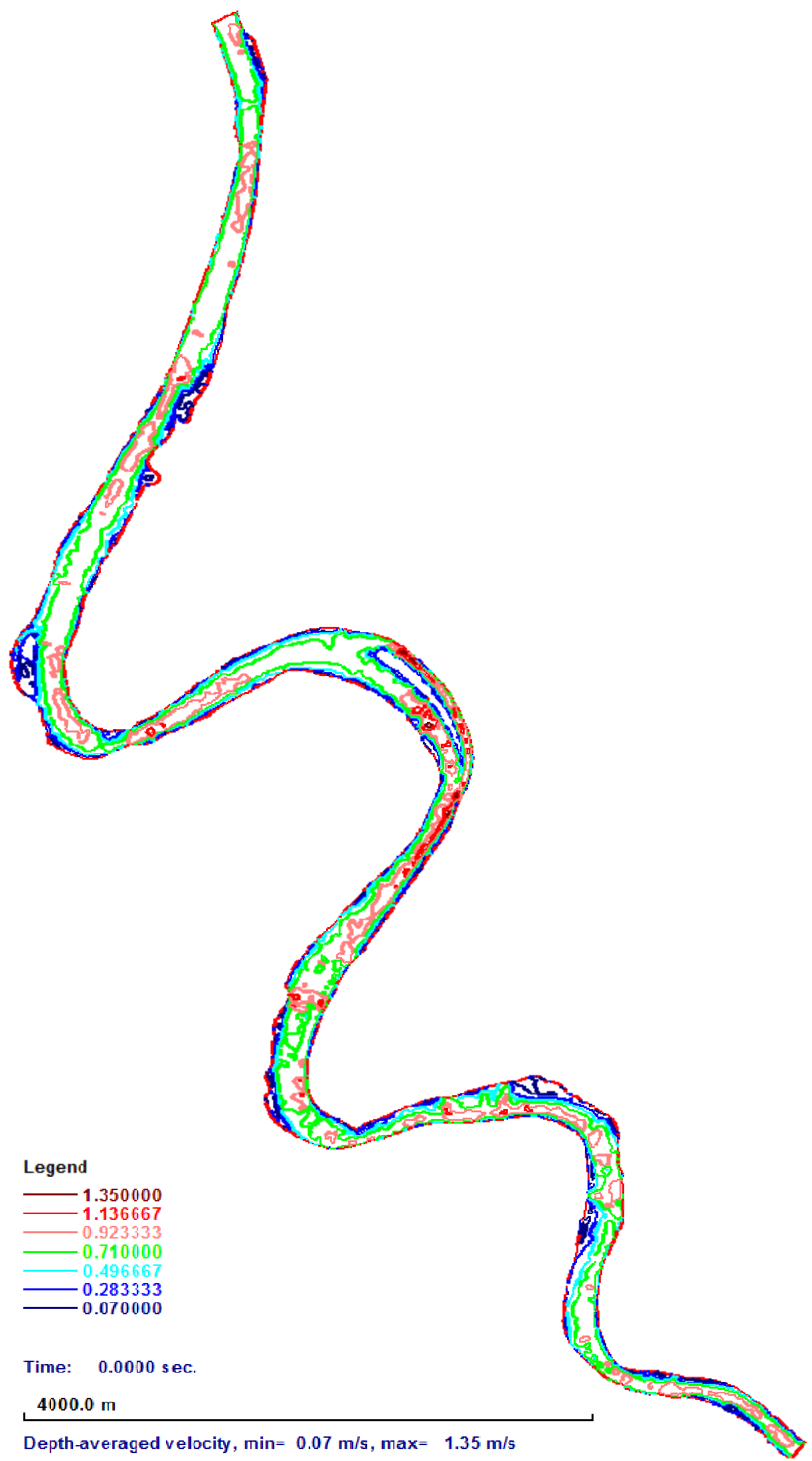

Fig. 7 The depth-averaged velocity distribution $(\mathrm{m} / \mathrm{s})$ in the Tigris River after the calibration for water discharge $530 \mathrm{~m}^{3} / \mathrm{s}$. 

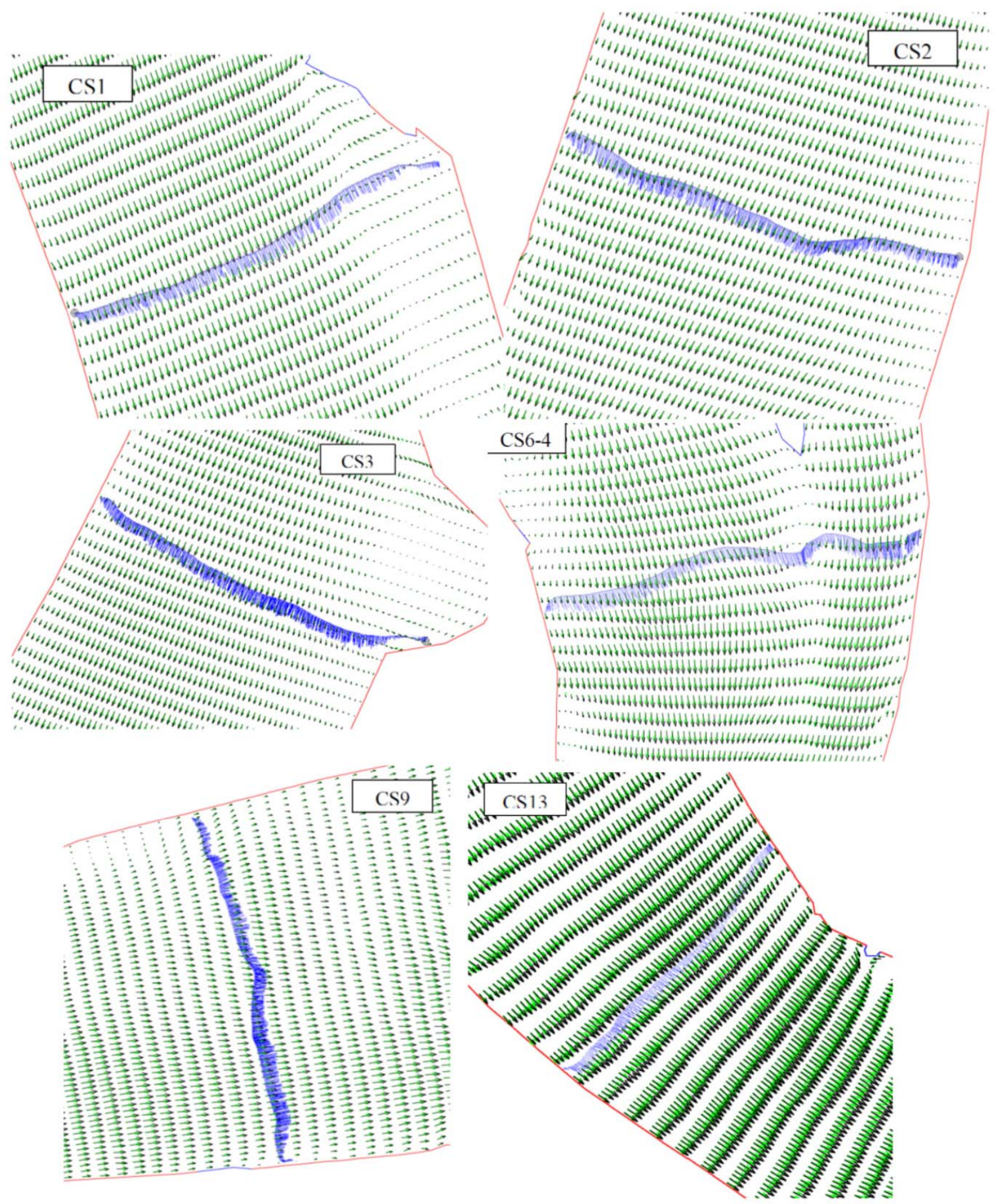

Fig. 8 The simulated velocity vectors on the water surface (black arrows) and on the riverbed (green arrows) with the measurements of the averaged depth velocity by ADCP (blue lines). 
Table 4 RMSE values for water surface profile $(\mathrm{m})$, velocity profile $(\mathrm{m} / \mathrm{s})$ and sediment concentration profile (mg/L) for validation process.

\begin{tabular}{ll}
\hline Validation & RMSE \\
\hline Water level & 0.046 \\
Velocity & 0.101 \\
Concentration & 0.085 \\
\hline
\end{tabular}

for the northern reach of the Tigris River in Baghdad. The aims of predicting future changes of river topography and morphology are to set guidelines for:

(1) Predicting locations of future sedimentations and the expected rate of deposition, which can help in: drawing future dredging plans and deciding whether to maintain the functionality of the water intakes or to improve the flooding capacity of the river;

(2) Finding out locations of future erosion which can help in warning of the possibilities of failure in river banks;

(3) Changes in navigation routes can be found, which can help to warn of expected shallow routes;

(4) River ecosystem and biodiversity can be predicted.

According to the available data and information about the study reach, some assumptions have to be set for simulating the future predictions as follows:

(1) River flow was assumed steady and equaled to the discharge that is used in the calibration $\left(530 \mathrm{~m}^{3} / \mathrm{s}\right)$;

(2) The corresponding inflow of sediment discharge was assumed constant with the same size fractions;

(3) The thickness of active and inactive bed layers were assumed to be $0.1 \mathrm{~m}$ and $10 \mathrm{~m}$ thick, respectively, along the study reach and of the same sediment fractions. The thickness of the inactive layer was considered according to the thickness of depositions found in a previous study [21];

(4) Bridge piers will not be considered in the river geometry to avoid the disturbance in the flow field, as well as computations of local souring around bridge piers, requiring a finer grid which is beyond the scope of current work.

Using a constant water discharge at $530 \mathrm{~m}^{3} / \mathrm{s}$, which is close to the average monthly discharge for the last 13 years, simulations of future predictions can help in establishing a comparison between the locations of deposition and their patterns from the simulation results of bed changes and deposition locations, those are recognized from the available aerial images in Google Earth and from other sources for the study reach during the period of 2002 to 2012. This comparison has a degree of importance because of the continuity of the dredging operations along the river in Baghdad that makes continuous monitoring for the river bed changes hard to conduct by researchers.

Long term prediction of three dimensional morphodynamic models for a large scale study reach would consume long computational time and monitoring efforts due to high potential computations and instability problems. So, the prediction period will be limited to 14 months.

\section{Results and Discussion}

The disequilibrium behaviour is the usual behaviour in a river that is responding to the local or global hydrologic changes, such as climate changes or human activities (regulation and damming). Such a river tends to adjust the channel dimensions and slope continuously by reducing channel width and increasing flow depth since both discharge and sediment load are decreased [22].

The sediment capacity of the Tigris River inside Baghdad is reduced, where the water surface slope is within the range 6.5 to $6.8 \mathrm{~cm} / \mathrm{km}$, corresponding to the discharges of the period (2009-2013). Upstream Baghdad, it is steeper between Samarra and Baghdad $(14 \mathrm{~cm} / \mathrm{km})$ as shown in the document of Ref. [22]. Also, the average cross sectional velocity was around $0.7 \mathrm{~m} / \mathrm{s}$. 


\subsection{Bed Changes}

Since the flow discharges and sediment loads were reduced by the headwater regulation system, so the Tigris River in Baghdad tends to deposit part of the eroded sediment upfront on the shallow part of the cross sections having lower velocity and, on the other hand, it deepens the incised route to fit its current hydrologic condition leaving the former wide section as a floodplain for the newer river as shown in Fig. 9. Higher depositions were distributed between circulation zones and meanders' inner banks, where the flow velocity is low.

The results of future predictions for the changes in the river bed showed that the Tigris River behaved as an under fit river [22]. The exception in the Tigris River inside Baghdad is that the river is confined by protected banks, where the bases of the banks are filled by stones, so the margin of sinuosity is limited.

The depth of the incision at some locations seemed to be exaggerated, where it reached the whole bed sediment layer as shown in Fig. 10 around station $2,000 \mathrm{~m}$ and $10,000 \mathrm{~m}$. This is attributed to the high depth of the bed sediment layer which is composed of easily erodible material. So, investigations about the real depth of the loose sediment layer and the characteristics of the strata underneath are required. Fig. 10 shows the changes in thalweg line elevations. It gives an indication of the potential threats of the river banks' collapse since erosion takes place below the protection base level especially in peaks of the meanders as shown in Fig. 11. Small parts of the protection had already collapsed on the outer bank meander at CS13 (Fig. 11c), which prompted the MoWR (Ministry of Water Resources) to drive in some sheet piles to stabilize the river bank.

Some depositions took the shape of longitudinal barriers parallel to the flow direction while the deposition behind the barriers towards the banks continues to develop as shown in Fig. 12. The front sides of the barriers with the relatively faster flow were built from the coarser sediments while in the back sides, the finer sediment was depositing.

The results of model showed that the net deposition/erosion rate was $67.44 \mathrm{~kg} / \mathrm{s}$ as an average along the study reach and the total deposition quantity was 2.12 million ton annually.

\subsection{Velocity Field}

In general, the range of the predicted depth-averaged velocity increased, where it reached up to $1.49 \mathrm{~m} / \mathrm{s}$ as shown in Fig. 13. Specifically, the velocity increased in the incised route zone and decreased in the shallow part of the section. The flow pattern became oriented and smoother compared with the pre-prediction case.

\subsection{Depositions in Reality}

Fig. 14 showed part of the depositions along the Tigris River in Baghdad. Google Earth photos captured on different dates, showed the size of the depositions relative to river width. The associated water discharges for the dates of the photos were added to the figure to give an indication of the water levels when the depositions are uncovered. Considering the predicted velocity distribution in the figure, it can be concluded that re-deposition at same sites is possible. So the prediction from the model can be close to the reality.

\subsection{Development of Islands}

Two islands are located within the study reach. The smaller one is located upstream of an acute meander (point and D in Fig. 9). This island is undergoing dredging. As shown in Fig. 12d, depositions were built up touching the island and extended downstream forming a pond in the shade of the island. This pond is a result of depositing more fine sediment, which means developing the island again. The second island (Kura'at Island), which is relatively the bigger, is at a bisecting meander. The origin of this island can be chute cut-off then it developed later to an island. Future predictions show that the front of the island is eroding while the width and the tail length of the island are increasing as shown in Fig. 15. The growth rate is faster towards the outer side of the meander and it gives 


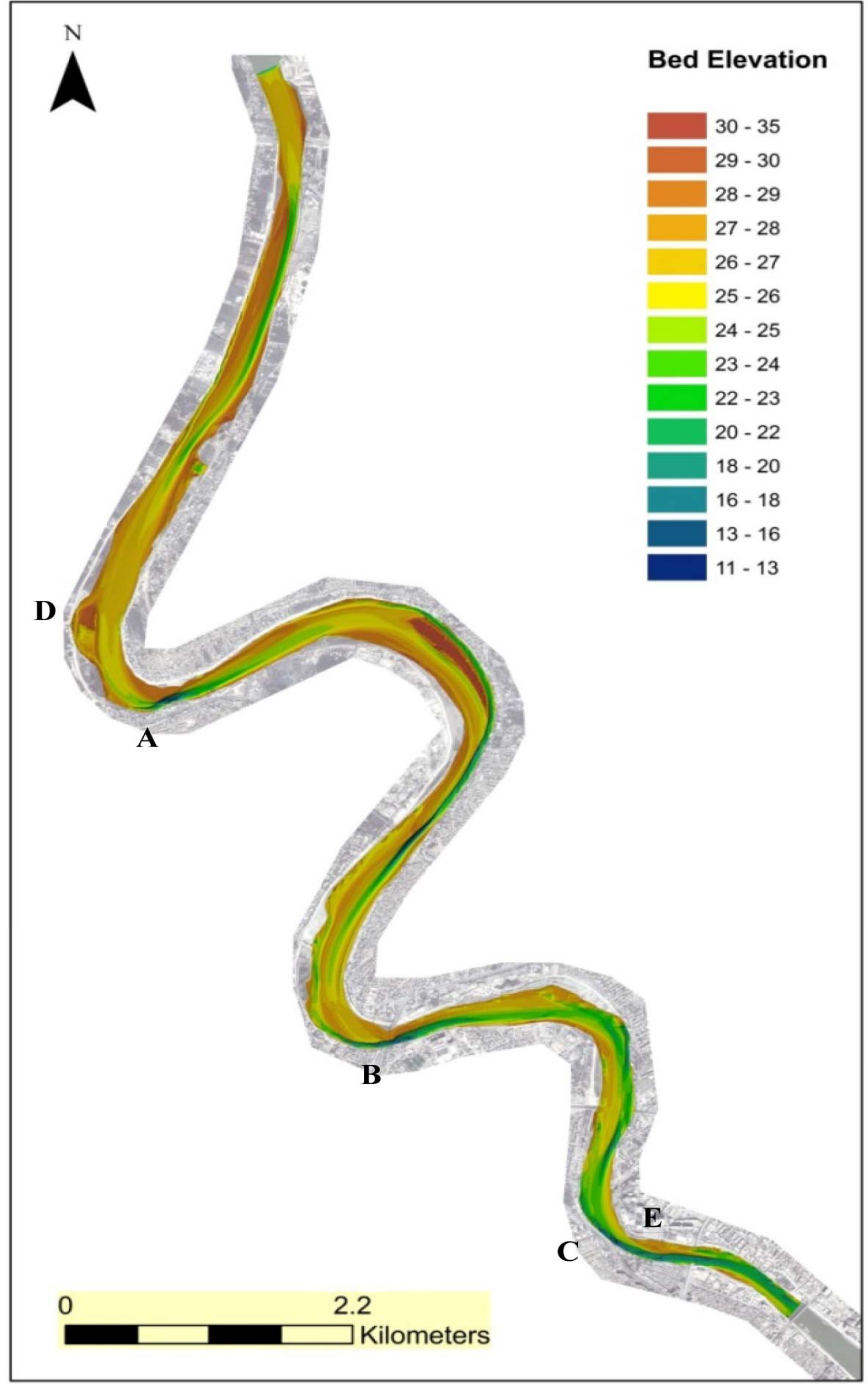

Fig. 9 The predicted bed elevations (m.a.s.l.) of the Tigris River. 


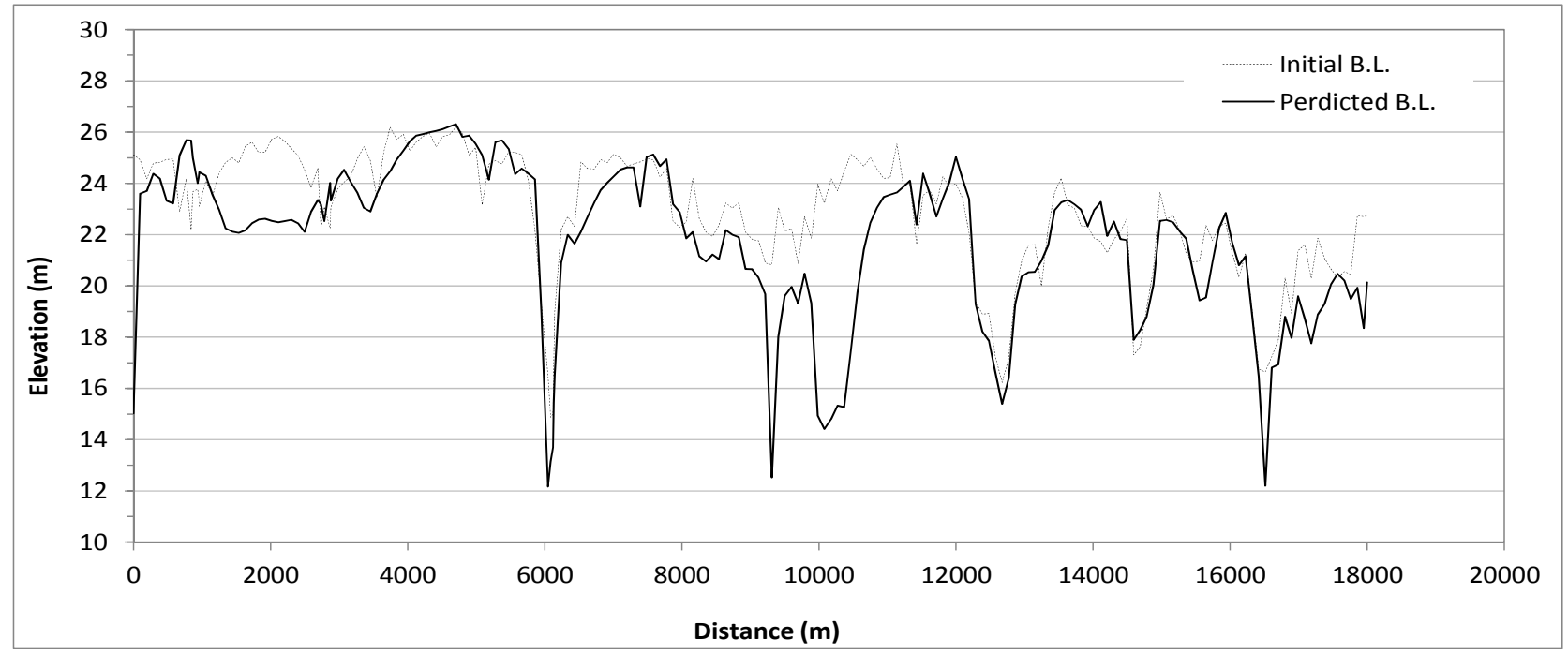

Fig. 10 The initial and the predicted elevations of the thalweg line of the Tigris River.

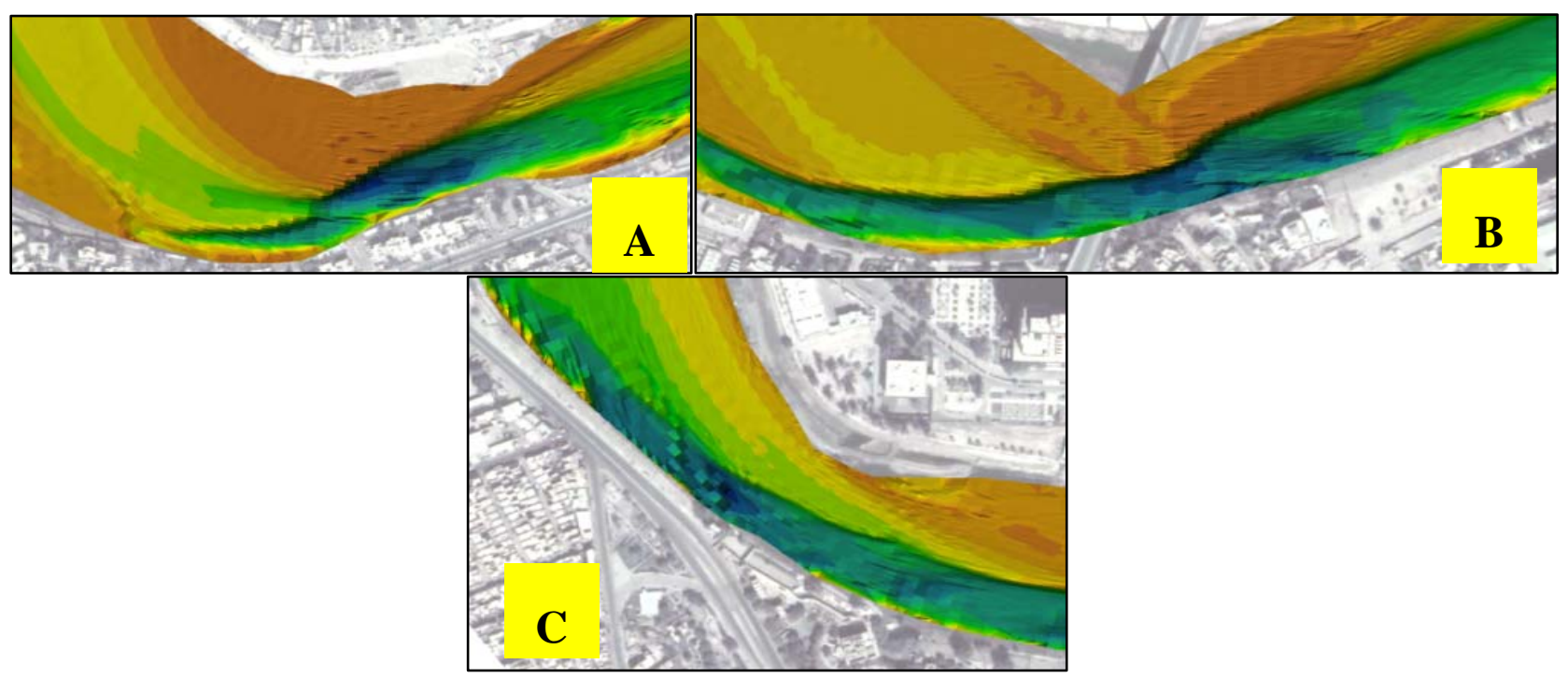

Fig. 11 The predicted locations of the potential threats of river banks collapse (Points A, B and C in Fig. 9).

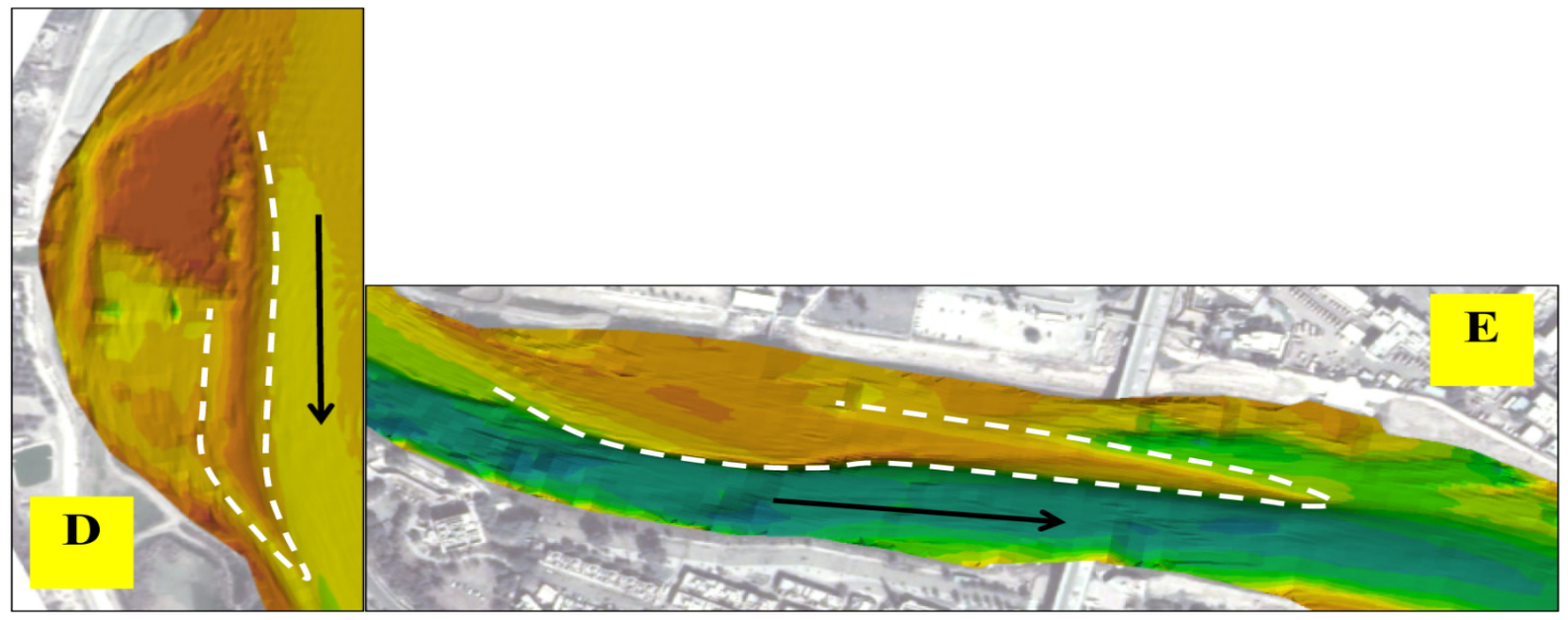

Fig. 12 Barrier depositions parallel to the flow direction (Points $D$ and $E$ in Fig. 9). 


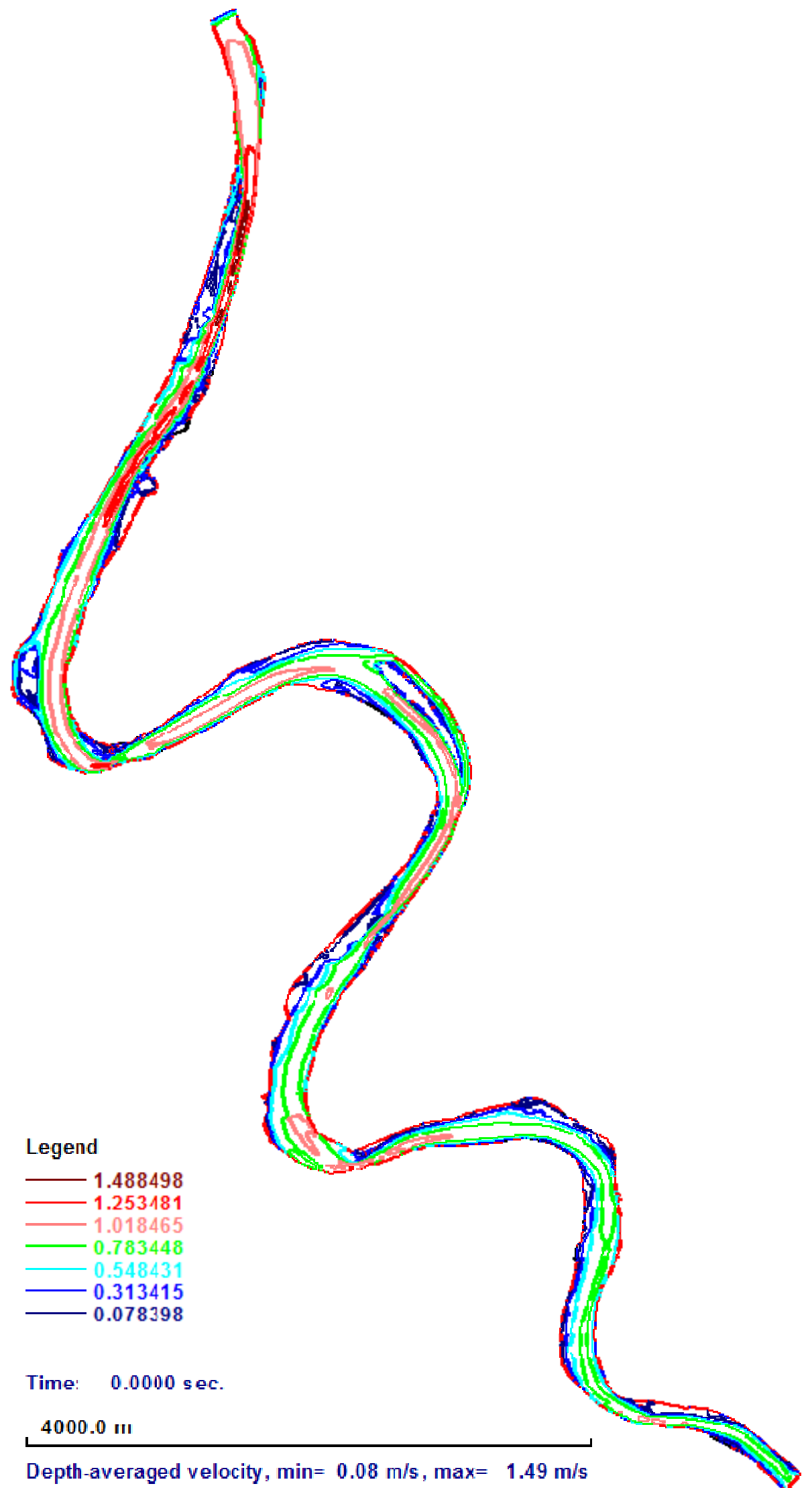

Fig. 13 The predicted distribution of the depth-averaged velocity $(\mathrm{m} / \mathrm{s})$ in the Tigris River for water discharge $530 \mathrm{~m}^{3} / \mathrm{s}$. 


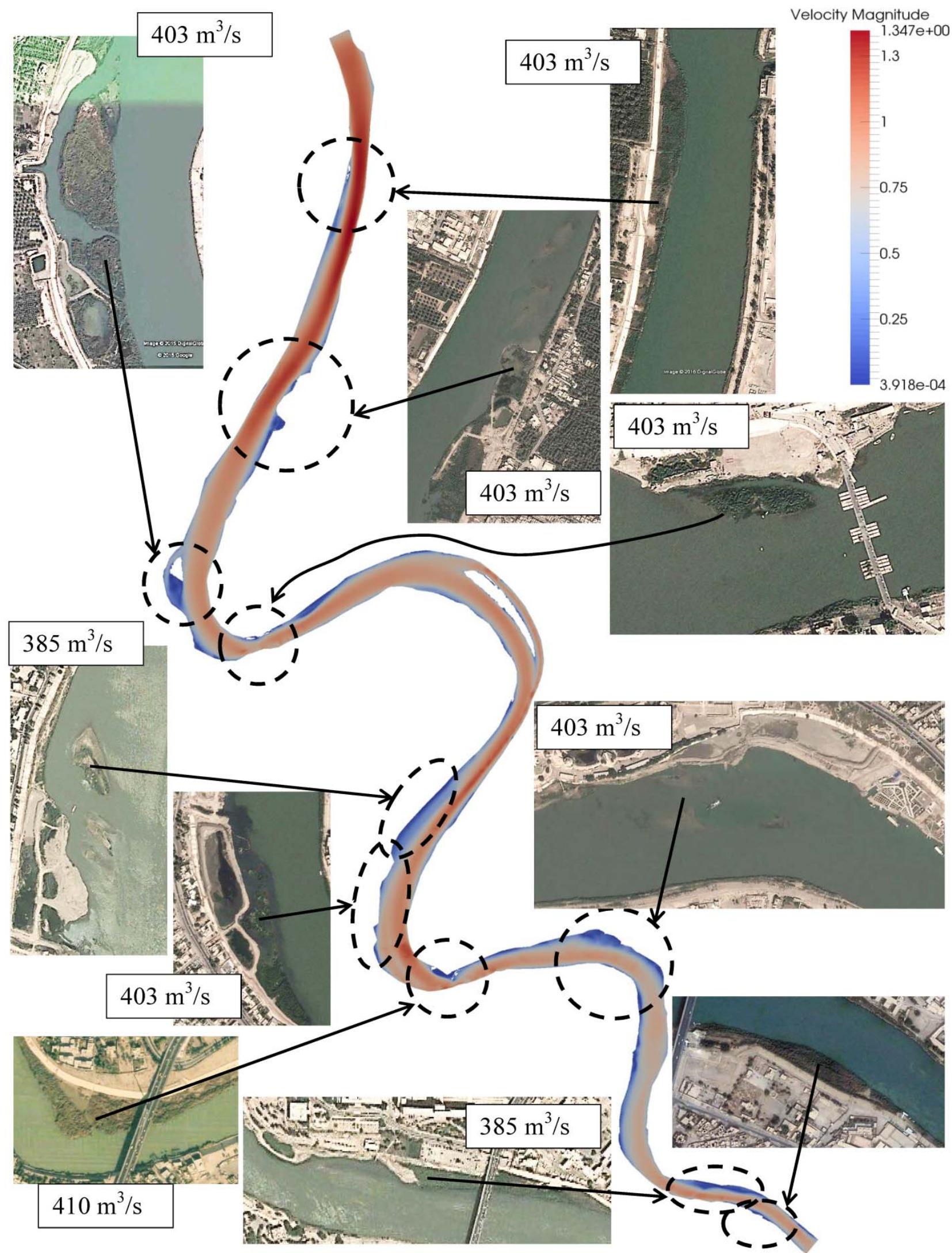

Fig. 14 The predicted sites of depositions in the SSIIM model and the depositions in reality including the discharges of the river. 


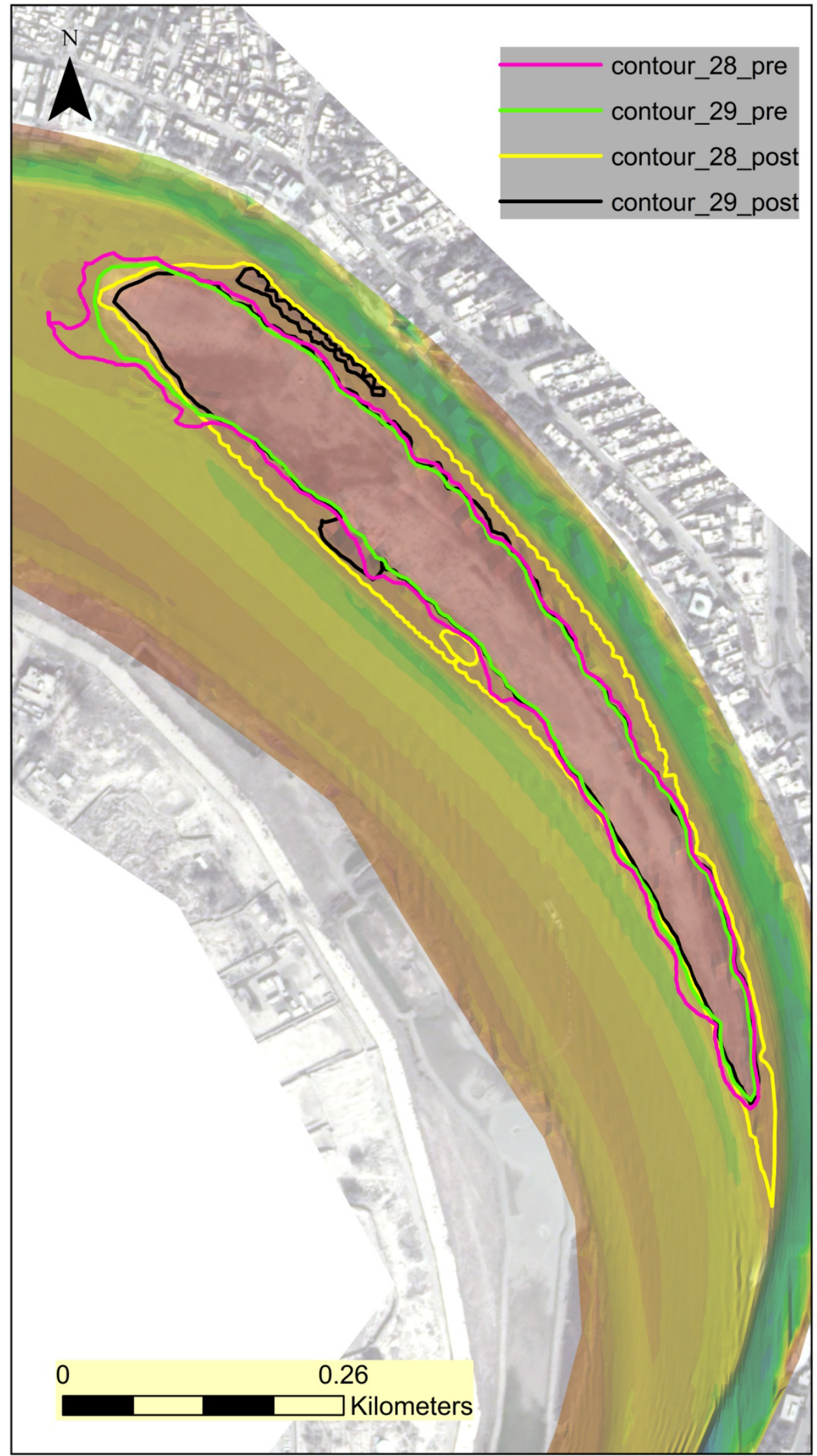

Fig. 15 The predicted development of the Kura'at Island. 


$$
\xi
$$


an indication of possible contact with the outer bank in the future, since the right branch of the meander is getting deeper and might develop to accommodate most of the flow over the whole cross section.

\subsection{Navigation Routes}

Fig. 16 show the predicted water depths along the Tigris River. Water depth was within the range of 2 to 4 $\mathrm{m}$ except for the incised route zone where the depth reached up to $15 \mathrm{~m}$. So navigation for small boats is still possible even in the zones close to the banks where the draught of small boats is less than about $1.2 \mathrm{~m}$. Caution should be taken seriously by passenger boats or ferries when navigating close to the banks. Port areas are either to be kept clean from depositions by dredging or should be extended into deeper water.

\section{Conclusions}

The results of implementation of the 3-D flow model on the Tigris River reach inside Baghdad for predicting the future bed changes, led to the following conclusions:

(1) The calibration of the SSIIM model succeeded in reproducing the water levels, velocity profiles and sediment concentration profiles at the cross sections used for this purpose. The validation process for other cross sections produced results of the same order of error. The SSIIM model has been found valid to be used for predicting future changes in the riverbed;

(2) The future predictions showed the Tigris River behaved like an underfit river tending to adjust the channel dimensions and the slope by deepening an incised route that fit more with its current discharges (water and sediment), and leaving the former wide section as a floodplain of the newer river;

(3) Higher depositions were distributed between circulation zones and meanders' inner banks, where the flow velocity is low;

(4) The erosion along the thalweg line gave an indication of the potential threats of the river banks' collapse and the bridge piers' instability;
(5) Some deposition took shape of longitudinal barriers, forming settling ponds for finer sediment to deposit behind the barriers towards the banks;

(6) The net deposition/erosion rate was $67.44 \mathrm{~kg} / \mathrm{s}$ as an average along the study reach and the total deposition quantity was 2.12 million tons annually;

(7) The locations of depositions are compatible with those of the river in the real world;

(8) The re-deposition in the model at the same real sites along the river indicated that sedimentation processes will continue in the river for the current hydrologic conditions and deepening of the incised route will also continue until the cross section of the river is adapted or the erosion reaches a stiffer bed layer that cannot be easily eroded;

(9) The pond formed by deposition in the shade of the small island, is working on re-build the dredged part again;

(10) The width and the tail length of the larger island (Kura'at Island) increased. A faster rate growth on the left side of the island may lead in the future to the connecting of the island with the near bank, and the right branch of the meander might develop to accommodate most of the flow over the whole cross section;

(11) Small boats of small draught have the possibility to port close to the river banks. Areas around ports have to be kept clean from sediment to let passenger boats or ferries porting easily. Otherwise ports have to be extended to deeper water.

\section{References}

[1] Olsen, N. R. B. 2014. A Three-Dimensional Numerical Model for Simulation of Sediment Movements in Water Intakes with Multiblock Option. Norway: Trondheim.

[2] Al-Ansari, N. A., Ali, S. H., and Taqa, A. S. 1979. "Sediment Discharge of the River Tigris at Baghdad (Iraq).” In Proceedings of the Canberra Symposium, IAHS-AISH Publ. no. 128, 399-407.

[3] Al-Ansari, N. A. 2013. "Management of Water Resources in Iraq: Perspectives and Prognoses.” J. Engineering 5 (8): 667-84.

[4] Al-Ansari, N. A. 2016. "Hydropolitics of the Tigris and 
Euphrates Basins.” Engineering 8 (3): 140-72.

[5] Al-Ansari, N. A., Ali, A., and Knutsson, S. 2014. "Present Conditions and Future Challenges of Water Resources Problems in Iraq.” J. Water Resources and Protection 6 (12): 1066-98.

[6] Al-Ansari, N. A., Ali, A., and Knutsson, S. 2015a. "Iraq Water Resources Planning: Perspectives and Prognoses.” In Proceedings of XIII International Conference on Civil and Construction Engineering, Jeddah, 26-27 January, Saudi Arabia.

[7] Ali, A. A. 2013. "Morphology of Tigris River inside Baghdad City.” Licentiate thesis, Department of Civil, Environmental and Natural Resources Engineering, Lulea University of Technology, Lulea, Sweden.

[8] Ali, A. A., Al-Ansari, N. A., and Knutsson, S. 2012. "Morphology of Tigris River within Baghdad City." Journal of Hydrology and Earth System Sciences 16: 3783-90. doi:10.5194/hess-16-3783-2012.

[9] Ali, A. A., Al-Suhail, Q., Al-Ansari, N. A., and Knutsson, S. 2014. "Evaluation of Dredging Operations for Tigris River within Baghdad, Iraq.” J. Water Resources and Protection 6 (4): 202-13.

[10] University of Technology. 1992. Training of Tigris River inside Baghdad City. Report Submitted to the Iraqi Ministry of Agriculture and Irrigation: Baghdad.

[11] Al-Ansari, N. A., Ali, A., Al-Suhail, Q., and Knutsson, S. 2015b. "Flow of River Tigris and Its Effect on the Bed Sediment within Baghdad, Iraq.” Open Engineering 5: 465-77.

[12] Ali, A.A., Al-Ansari, N. A., Al-Suhail, Q., and Knutsson, S. 2016a. "Total Sediment Load in Tigris River at Baghdad City.” J. Hydrological Sciences V. 62, 8.

[13] Ali, A. A., Al-Ansari, N. A., Al-Suhail, Q., and Knutsson S. 2016b. "Bedload Transport in Tigris River in Baghdad City.” J. Earth Sciences and Geotechnical Engineering V. 7,5 .
[14] Van Rijn, L. C. 1993. Principles of Sediment Transport in Rivers, Estuaries and Coastal Seas. Aqua Publications: Amsterdam.

[15] Van Riin, L. C. 1984. "Sediment Transport, Part III: Bed Forms and Alluvial Roughness.” Journal of Hydraulic Engineering 110 (12): 1733-54.

[16] Zhang, Q., Hillebrand G., Moser H., and Hinkelmann R. 2015. "Simulation of Non-uniform Sediment Transport I German Reservoir with the SSIIM Model and Sensitivity Analysis.” Presented at European proceedings of the 36th IAHR World Congress: Deltas of the Future and what happens upstream. Netherlands, The Hague 28 June-3 July.

[17] Mosselman, E. 2012. "Modelling Sediment Transport and Morphodynamics of Gravel-bed Rivers.” In Gravel-Bed Rivers: Processes, Tools, Environments, edited by Church M., Biron, P. M., and Roy, A. G. Chapter 9. Chichester, UK: John Wiley \& Sons, Ltd.

[18] Tuijnder, A. P. 2010. "Sand in Short Supply; Modelling of Bedforms, Roughness and Sediment Transport in Rivers under Supply-Limited Conditions.” Ph.D. thesis, University of Twente.

[19] Dorfmann, C., and Knoblauch, H., 2009. "Calibration of 2-D and 3-D Numerical Models of a Large Reservoir Using ADCP Measurements.” In Proceeding of 33rd IAHR World Congress: Water Engineering for a Sustainable Environment, Canada, 9-14 August.

[20] Geohydraulique. 1977. Tigris River Training Project within Baghdad City. Report Submitted to the Iraqi Ministry of Irrigation: Paris.

[21] Hickin, E. J., 1995. River Geomorphology. Chichester, UK: Wiley.

[22] MoWR (Ministry of Water Resources). 2012. “Distances, wave travel times and water surface slopes between gauging stations along Tigris and Euphrates Rivers.” Personal communications with the staff of the National Center for Water Resources Management, Baghdad. 